\title{
The Electoral Foundations to Noncompliance: Addressing the Puzzle of Unlawful State
}

\section{Aid in the European Union*}

\begin{abstract}
Electoral institutions shape the incentives of governments to rely on distributive measures and to comply with international obligations because of the misalignment they may engender between the collective objectives of a government party and the individual objectives of its members in the legislature. We use this argument to explain the puzzle of unlawful state aid measures in the European Union (EU). Existing theories of EU compliance and implementation offer no convincing explanation to their persistence and patterns. Employing data from 2000 to 2012, we find that an increase of district magnitude improves compliance. However, compliance decreases with higher magnitude where either party leaders have no control over the ballot rank or other electoral rules strengthen the incentives to search for a personal vote. We also provide evidence for the effects of electoral reforms on compliance. These results have implications for the broader literature on compliance with international regimes.
\end{abstract}

Keywords: Compliance, Electoral institutions, European Union, State aid

\footnotetext{
* Preliminary versions of this paper have been presented at the Conference of the ECPR Standing Group on the European Union, The Hague, June 2014, the Conference of the European Political Science Association, Edinburgh, June 2014, the XXVIII Conference of the Italian Society of Political Science, Perugia, September 2014. For comments and suggestions we are grateful to Bernard Steunenberg, Ellen Mastenbroek, Lars Mäder, Thomas Winzen, Andrea Ceron and panel participants.
} 


\section{Introduction}

There is growing evidence that electoral institutions systematically shape the incentives of politicians to provide distributive policies (e.g. Persson and Tabellini 1999, 2000, 2003, 2004; Milesi-Ferretti et al. 2002; Hallerberg and Marier 2004; McGillivray 2004; Cao et al. 2007; Edwards and Thames 2007; Chang 2008; Zahariadis 2010; Rickard 2012a, 2012b; Franchino and Mainenti 2013; see also Carey and Hix 2013). In this article, we argue that these institutions also influence the propensity to comply with international laws. Recently, Rickard (2010) has found that the electoral formula (i.e., a majoritarian or proportional electoral system) affects compliance with the rules on narrowly targeted transfers of the World Trade Organization (WTO). We extend her argument further following the seminal works of Persson and Tabellini (1999, 2000) and Carey and Shugart (1995), and we show how electoral institutions (i.e. district magnitude and ballot structure) affect the propensity to comply with the European Union (EU) rules on the provision of state aid - a key pillar of EU competition policy.

EU governments can adopt a state aid only upon notification to and approval by the European Commission. They nevertheless frequently implement these measures without notification, even though it is very likely that they will be detected and sanctioned. As discussed in detail in the next section, existing theories of EU compliance and implementation offer no convincing explanation to the persistence and patterns of unlawful state aid measures.

We argue that electoral institutions shape the incentives to comply because of the misalignment they may engender between the collective objectives of a government party and the individual objectives of its members in the legislature. While the costs associated with noncompliance are likely to exceed the benefits from the perspective of the government, it may be the opposite for the individual legislators, depending on their need to build a personal reputation that is distinct from that of their parties. Since electoral institutions shape these 
incentives and government survival depends on parliamentary support, electoral institutions should affect the propensity of governments to comply. We find that compliance improves as district magnitude increases, but it worsens with higher magnitude if either party leaders have no control over the ballot rank or other electoral rules strengthen the incentives to cultivate a personal vote. For within-country effects, we also show that electoral reforms provide evidence that is consistent with these results.

This article extends and qualifies Rickard's (2010) findings. As argued in several studies (e.g. Mansfield et al. 2002), because of the propensity of voters to sanction leaders that violate international rules, democratic regimes are more likely to comply than authoritarian ones. However, this argument cannot explain contrasting findings on the impact of democratic institutions (Simmons 2000; Dai 2006) and, in particular, the significant differences in compliance that we find among democracies. Rickard (2010) argues that the different electoral formulas operating in democratic regimes can shed light on these differences. Voters in majoritarian electoral systems may reward leaders for violating some international agreements and this can explain lower compliance. In this article, we show that the impact of the electoral formula is also mediated by the structure of the ballot. So compliance may be also lower in proportional representation systems that include rules that heighten the need to cultivate a personal vote.

The article also innovates on several dimensions with regard to the existing research on EU compliance and implementation. In a recent comprehensive review, Treib (2014) concludes that the substantive focus has been predominantly on directives (rather than regulations), on transposition (rather than application and enforcement) and on positive (rather than negative) integration (i.e. prescriptive rather than proscriptive provisions). We focus here on the application and enforcement of a regulation with provisions proscribing the adoption of certain state aid measures. Treib $(2014,19)$ also notes that studies on enforcement and 
application have been almost exclusively qualitative. Ours is not. Lastly, the centralized features of this policy allow us to produce a sufficiently valid measure of compliance, which can otherwise be a challenge in similar studies.

The next section introduces the EU state aid policy and explains why the patterns of unlawful state aid measures are puzzling. Then, we employ the literature on the effects of electoral systems on public spending to develop three hypotheses on the relationship between electoral institutions and propensity to comply. Next, we present the data and the operationalization of the variables. We finally discuss our findings and provide concluding comments.

\section{The puzzle of unlawful state aid measures}

According to EU law, a measure is considered a state aid if it provides a selective, state funded, and otherwise unattainable economic advantage to a company, a group of companies, an economic sector or a geographical area. For instance, state aid may take the form of debtwrite offs or soft loans for rescuing companies in difficulty, tax exemptions or direct grants for groups of companies or economic sectors, and interest subsidies for developing business and regional infrastructures. Article 107 of the Treaty on the Functioning of the European Union (TFEU) states that any aid that distorts or threatens to distort competition is incompatible with the internal market. Then, it lists the measures that either are or may be compatible. Article 108 TFEU specifies that a government can adopt a new measure only upon notification to and approval by the Commission (or, exceptionally, by a unanimous Council). Lastly, Council Regulation 659/1999 stipulates that, upon notification, the supranational executive must proceed to a preliminary investigation and decide within two months whether the measure constitutes aid and whether to approve it. If the Commission has doubts about its compatibility, it proceeds to a formal investigation and it must decide within 
eighteen months whether the measure constitutes aid and, then, whether to approve, conditionally approve or reject the proposed programme.

In addition to new aid, the Commission can investigate any aid put into effect without notification, that is, unlawful aid measures. Between 2000 and 2012, it has uncovered 419 of such measures. In other words, eleven out of one hundred measures that are implemented in any given year are unlawful. Figure 1 shows the proportions of these measures over the total number of aid measures across time and countries.

Existing theories fall short in explaining these patterns. Consider the main determinants of compliance recently identified by Treib (2014). ${ }^{1}$ EU-level factors, such as the discretion granted to national administrations, are irrelevant because they vary only across policies. The number of domestic veto players is meaningful only in case of transposition which requires the adoption of national legal measures. The misfit between supranational policy objectives and pre-existing domestic legacies is larger for new member states, but ten of these countries display the best compliance records - they are clustered at the right end of Figure 1. These cross-country patterns also do not reflect distinct cultures of compliance (cf. Falkner et al. 2005, 2007, 2008). Denmark and Finland, where a diffused respect for the rule of law would suggest observance, have a surprisingly high propensity to adopt unlawful measures (but Sweden does not). Compliance is higher in all the countries belonging to the so-called world of domestic politics where political interference should indicate otherwise. Greece, Portugal, France and Luxembourg cover the full spectrum in Figure 1 despite of the fact that they belong to the same world of compliance. Finally, a cluster of states that should display serious shortcomings in enforcement and application include both the most compliant countries (Czech Republic, Slovenia and Slovakia) and the worst offenders (Ireland and Hungary). 


\section{FIGURE 1 ABOUT HERE}

Other important determinants highlighted by Treib (2014), such as the ideological orientation of the incumbent government and the administrative capabilities of a country, only partially explain these patterns, as it will be shown below. Also, there is no longitudinal trend or detectable fluctuations associated with the business cycle.

The persistence of the phenomenon and its country variation is therefore puzzling because it is very likely that any measure that is implemented without notification will be detected sooner or later. The Commission can investigate any alleged unlawful aid of its own initiative or upon a third party compliant. Interested parties can lodge online a complaint against alleged unlawful measures without their identity being disclosed. They can also bring direct action before their national courts, which must assess the case regardless of the existence of any parallel supranational procedure. Once a suspicious measure has been detected, the Commission can demand suspension and provisional recovery of the aid until it has decided on its compatibility. And if a measure turns out being incompatible, it would order a recovery of the funds, including the accrued payable interests. Thus, governments will very likely face the embarrassment of having to recover the aid. Why does then noncompliance persist over time? What explains these patterns?

\section{Geographically-targeted measures, electoral systems and compliance}

\section{Geographically-targeted measures and electoral institutions}

Our point of departure is Persson and Tabellini's $(1999,2000)$ seminal model of competition between two office-seeking parties which offer a district-specific transfer and a public good to the electorate. These scholars show that, in equilibrium, spending on district-specific transfers is higher, and on the public good lower, in a polity with three districts than in one 
with a single district. In the former case, the chance of reelection is maximized if spending is shifted from the public good to transfers in favor of marginal districts. ${ }^{2}$ Early evidence has not been encouraging, ${ }^{3}$ but later studies have shown more promise. For instance, Chang (2008) reports slightly higher district-specific spending, close to elections, in countries with a single veto player and single-member electoral districts. Rickard (2012a) reports higher spending on subsidies in countries with majoritarian or mixed-member majoritarian electoral systems. In the more specific case of subsidies for the manufacturing sector, Rickard (2012b) finds more spending in majoritarian systems when manufacturing employment is geographically concentrated, and the opposite when employment is diffuse. Many of these works solely distinguish, with some coding differences, between single-member district and other systems (e.g. Cao et al. 2007; Chang 2008; Persson and Tabellini 2003, 2004; cf. Rickard 2012a, 2012b), ignoring the considerable heterogeneity of the latter group. After all, the model of Persson and Tabellini $(1999,2000)$ suggests that district magnitude should drive district-specific spending.

District magnitude, as well as ballot structure, matter because they may 'undermine to varying degrees the alignment of [...] collective goals [i.e. maximizing party seats in the legislature] and the individual goals of candidates and legislators [i.e. (re)election]'(Shugart 2013, 818). These features specify how seats are allocated among candidates within parties and affect the incentives of candidates to develop personal reputations distinct from those of their parties (Carey and Shugart 1995, 417-8; see also Shugart et al. 2005). And usually these reputations are built by securing measures that deliver district-specific benefits.

Carey and Shugart (1995) identify three key characteristics of the ballot which, interacting with district magnitude, shape the incentives to build a personal reputation. The first is ballot control, that is the degree of control party leaders exercise over the access to their party's label. If leaders have control over the ballot, like in closed-list PR systems, the incentives to 
cultivate personal reputations decrease with the magnitude of the district. Only if there are few seats in a district, with correspondingly few and identifiable candidates, politicians may have incentives to highlight their personal record or characteristics. On the other hand, if leaders do not have control over the ballot, like in open-list PR systems, candidates of the same party must compete against each other to secure a seat. As the magnitude of the district increases, there are stronger incentives to distinguish oneself from a larger crowd of copartisans.

The second characteristic is vote pooling, that is whether the votes cast for one candidate of a given party contribute also to the number of seats won in the district by the party as a whole; while the last characteristic is whether voters are allowed to cast only a single vote for a party, multiple votes, or a single vote for a candidate. For instance, the electors of the Danish Folketinget can choose either a candidate or a party, and votes are pooled across the whole party for the assignment of seats to parties. In the Irish single transferable vote system, voters rank candidates and pooling takes place across candidates only. The incentives to cultivate a personal reputation increase with less pooling and multiple or candidate-level voting, especially if the district magnitude increases because intra-party competition becomes more intense.

Admittedly, evidence for the impact of district magnitude and ballot structure on spending is still limited. For instance, as a qualified support for Persson and Tabellini's (public goodrelated) expectation, Edwards and Thames (2007) find that education expenditure increases with district magnitude in systems with low incentives to cultivate a personal vote, but it decreases in systems with high incentives. Golden and Picci (2008) illustrate the importance of the open-list in PR systems by showing how it biases infrastructural investment. Other works that investigate the impact of these electoral institutions on spending, such as Hallerberg and Marier (2004) and Rickard (2012b), do not subject Carey and Shugart's 
expectations to test. Closer to our interest, Franchino and Mainenti (2013) find that EU governments spend less on state aid when high district magnitude is associated with ballot control, party-based voting and pooling. In these circumstances, fewer measures are also adopted. On the other hand, more measures are implemented when high magnitude is combined with a lack of ballot control.

\section{Beyond spending: electoral institutions and compliance}

There is growing evidence that electoral institutions shape public spending, but why would they influence compliance with EU law as well? Couldn't governments just spend more on these policies, without running afoul of EU provisions? As discussed above, the persistence and patterns of unlawful aid measures are puzzling. An unlawful aid will be most likely detected sooner or later, either by the Commission or by an interested party, since the cost to lodge a complaint is negligible. Even if there is some probability of escaping the Commission's radar, this cannot explain cross-country variation, unless you implausibly argue that the supranational executive is biased in performing its duties.

In order to understand why governments may be willing to run these risks, we should start from the premise that government survival in parliamentary systems rests on the ongoing support of a party or a coalition of parties in the legislature, ${ }^{4}$ and the incentives of legislators may not be aligned with the collective goals of their party. From the government perspective, implementing the measure without notification carries the risk of detection, the embarrassment of recovery and the criticism of incompetence, having invested scarce time and resources to no avail. But these calculations look quite different from the perspective of the politician representing the constituency benefitting from the measure and whose individual reputation for dealing with a pressing local problem is on the line. The supranational procedure is costly and time consuming; it can take up to twenty months for a 
decision. Detection occurs several months after the adoption; thirty percent of the unlawful measures adopted between 2000 and 2012 have been detected more than one year after their implementation. Legislators can meanwhile preserve their reputation, taking credit for the attempted action, and eventually blaming the Commission for blocking the measure.

Since electoral institutions can shape the severity of the misalignment between the goals of a government party and those of its members, they can also influence the degree to which governments eventually comply with the procedure. Evidence in favour of this expectation has been recently produced by Rickard (2010) who finds that governments elected via majoritarian electoral rules are less likely to comply with the restrictions on narrowly targeted transfers, agreed within the WTO, than governments elected via proportional representation. Even stronger evidence, because noncompliance in this context may have serious personal implications, is offered by Chang and Golden (2007). These scholars show that, at high levels of district magnitude, (the perception of) corruption is greater in open-list than in closed-list PR systems. In some circumstances, the opposite is true at low levels of district magnitude. ${ }^{5}$ If electoral institutions shape the incentives to undertake illegal activities, such as corruption, for the search of the personal vote, they should also influence compliance with EU law for the sake of securing geographically-targeted measures which run afoul of its provisions. In conclusion, the way electoral institutions influence the propensity for geographicallytargeted spending, as discussed in the previous section, should shape compliance with EU provisions on state aid control in a similar way. This brings us to a set of expectations. The first one follows Persson and Tabellini (1999, 2000) and the work of Rickard (2010) on compliance. It simply states that the lower the district magnitude, the higher the likelihood of adopting unlawful measures (H1).

The next expectations take seriously Carey and Shugart's (1995) contribution on the interactive effects of electoral rules on the search for the personal vote, as Chang and Golden 
(2007) do in the case of corruption. Let us focus first on the interaction between ballot control and district magnitude. We should expect that if party leaders have control over the ballot, the lower the district magnitude, the higher the likelihood of adopting unlawful state aid measures. Conversely, if party leaders have no control over the ballot, the higher the district magnitude, the higher the likelihood of adopting unlawful state aid measures $(\mathrm{H} 2)$. In other words, the marginal effect of district magnitude on the likelihood of adopting unlawful measures should be negative if party leaders have control over the ballot; it should be positive if party leaders have no such control.

Following the advice of Berry et al. (2012) to exploit fully the symmetric feature of theories positing interactions, what would therefore be the effect of ballot control on the likelihood of adopting unlawful measures? Compared to open-list systems, a closed-list system should unequivocally reduce the incentives to pursue the personal vote and, therefore, decrease the propensity to adopt unlawful measures, for any value of district magnitude. However, this effect should be weaker when few seats are available in the district because politicians in closed-list systems would nevertheless be tempted to highlight their personal record when competing against few other candidates (Carey and Shugart 1995, 431; Shugart 2013, 819). In other words, the marginal effect of ballot control on the likelihood of adopting unlawful measures should be negative at all values of district magnitude; this effect should be weakest when district magnitude is at low levels and it should strengthen in magnitude as district magnitude increases. As we will explain in more details below, single-member-district systems are assumed as having no ballot control, so this expectation is only meaningful for electoral systems with district magnitude higher than one.

Let us move on now to the interaction between district magnitude and the other electoral rules. We should expect that, as electoral systems provide for less pooling and for multiple or candidate-level voting (i.e. as these rules induce more search for the personal vote), the 
higher the district magnitude, the higher the likelihood of adopting unlawful state aid measures (H3). In other words, the marginal effect of district magnitude on the likelihood of adopting unlawful measures should be positive at all values of personal vote-inducing electoral rules. This effect should be weakest when these rules are at their lowest level (e.g. in case of pooling and party-level voting) and it should strengthen in magnitude as their value increases (e.g. in case of no pooling and multiple or candidate-level voting). The symmetric proposition is straightforward: the marginal effect of personal vote-inducing electoral rules on the likelihood of adopting unlawful measures should be positive at all values of district magnitude; this effect should be weakest when district magnitude is at its lowest levels and it should strengthen as district magnitude increases. Again, since single-member-district electoral systems have exclusively candidate-level voting and no pooling, i.e. the highest values in terms of personal vote-inducing electoral rules, this proposition is only meaningful when district magnitude is higher than one. The next sections subject these expectations to test.

\section{Data and variables}

\section{Unlawful state aid measures}

There are several benefits of focusing on the EU policy of state aid control. First, a state aid fits neatly the definition of distributive policy provided by Weingast et al. $(1981,644)^{6}$ since it provides a selective financial benefit to social groups and is geographically concentrated. Information on state aid measures can therefore be appropriately used to test hypotheses related to distributive policies, as works using government subsides do (Chang 2008; Rickard 2012a). Second, determining noncompliance is straightforward since national governments can implement state aid only upon notification to and approval by the Commission. Third, this procedure has been consolidated over the past decades (Aydin and Thomas 2012, 533- 
537; Cini and McGowan 2008, 175; Kassim and Lyons 2013, 8-9). Data on EU state aid are now comprehensive in terms of coverage of transactions and economic sectors and are highly comparable across countries since they fall under common EU legal criteria (Franchino and Mainenti 2013).

We employ the information on unlawful aid to industry and services available from the official database of the European Commission, ${ }^{7}$ covering the period from 2000 to 2012 . In other words, we consider all the unlawful aid that has been investigated by the Commission following the procedure codified in Council Regulation 659/1999. The dependent variable, Unlawful Measures, is the ratio between the number of unlawful aid measures - those that have been implemented either without notification to the Commission or before the Commission had taken a decision - over the total number of measures adopted by a given member state in a given year. ${ }^{8}$

\section{Electoral institutions}

We begin with the District Magnitude of an electoral system - an explanatory variable at the centre of our expectations. We have computed the weighted average district magnitude of each electoral system that member states have employed between 2000 and 2012. In case of majoritarian and proportional systems, the value of District Magnitude is equal to the ratio between the number of assembly seats and the number of electoral districts, at the electoral tier at which votes are translated into seats. In case of proportional multi-tier systems and mixed systems, we first computed the magnitude of each tier by dividing the number of seats assigned or won at a given tier in a given election by the number of electoral districts at that tier. We then summed the resulting tier-level values, weighted by the proportion of tier-level seats over the assembly size. ${ }^{9}$ 
Ballot Control is a dummy variable taking the value of one if a large majority of the assembly is elected under a close-list electoral system. ${ }^{10}$ For the remaining rules on pooling and votes, we employ the data collected by Johnson, Wallack and their collegues (Johnson and Wallack 2007; Wallack et al. 2003). We use a syncretic variable Pool-Vote Rules that averages the scores of the 'pool' and 'vote' indices produced by these scholars (for a similar procedure see Edwards and Thames 2007). Higher values indicate that these rules strengthen the incentives to search a personal vote. We consider also an alternative measure that adds up the scores of these two indices.

\section{Control variables}

We control for some additional factors that may influence compliance. First, the political business cycle model suggests that governments have the incentives to manipulate the level of unemployment through, for instance, higher public investment in order to maximize the chances of winning the next election (Nordhaus 1975, 174). Unlike other contributions (e.g. Aydin 2007; Zahariadis 2010), Chang (2008) has recently found that closeness to elections leads to slightly higher district-specific spending in some circumstances. An approaching electoral competition may therefore make governments more cavalier about complying with EU provisions. The variable Election takes the value of one in the year preceding an election in a given country and zero in the other years. In the election year, the value is the weighted pre-election period of the year. ${ }^{11}$

Second, left-wing governments may be more inclined to public investment than right-wing governments either because of a predisposition to believe in beneficial government intervention in the economy or because of the benefits accruing to key left-wing constituencies, such as manufacturing workers, underemployed and unemployed (Hibbs 1977). A partisan effect has been found in several studies on compliance (e.g. Falkner et al. 
2005, 2008; Jensen 2007; Jensen and Spoon 2011; Mastenbroek and Kaeding 2006; Sedelmeier 2012; Toshkov 2007, 2008) but corroborating evidence is weak in the specific case of distributive spending (Franchino and Mainenti 2013, 505). We can nevertheless concede that greater willingness or pressure to spend of left-wing governments could be translated in greater propensity to escape the constraints of EU law. The underlying policy dimension is the traditional left-right economic cleavage, pitting market liberals, favoring a small state and low taxes, against interventionists, supporting public spending and a larger government. We therefore employ the 'taxes v. spending' dimension used in the expert surveys on party positions by Laver and Hunt (1992) and Benoit and Laver (2006). The dimension ranges from 1 for a party that promote raising taxes to increase public services to 20 for one that promotes cutting public services to cut taxes. Government Preference is the sum of the positions of each government party along this dimension, weighted by its share of ministerial portfolios.

Third, noncompliance may be accidental rather than intentional as the management approach to compliance would suggest (e.g. Chayes and Chayes 1995). Some national administrations are less experienced than others in dealing with EU policies and a failure to notify a measure could simply reflect gaps in administrative and legal know-how. Administrative experience has indeed been identified as an important facilitator of compliance (e.g. Berglund et al. 2006; Haverland et al. 2011; Kaeding 2006; Steunenberg and Rhinard 2010). Since experience is generally gained over the years, we control for the length of EU membership of each country in a given year. Years in $E U$ is (the logarithm of) the number of years since joining the EU. This variable is also a measure of the misfit that is likely to exist, especially in new member states, between EU state aid policy principles and pre-existing legacies. Finally, we control for the GDP per capita to account for different levels of economic development across the EU, which may influence the propensity to spend and, therefore, 
comply. This variable has also been used as proxy for administrative capacity - another facilitator of compliance (e.g. Berglund et al. 2006; Börzel et al. 2010, 2012; Falkner et al. 2005; Haverland and Romeijn 2007; Hille and Knill 2006; Kaeding 2006; König and Mäder 2013; Mbaye 2001; Perkins and Neumayer 2007). Descriptive statistics of the variables we employ in the analysis are available in Table A1 in the Appendix.

\section{Explaining the puzzle of unlawful state aid measures}

Our first expectation is a straightforward relation between district magnitude and unlawful measures, while the second and third expectations posit two interactions, the first between district magnitude and ballot control, the second between district magnitude and the other electoral rules shaping the incentives to search for the personal vote. Therefore, we employ the following general specification

$Y_{i t}=\alpha_{0}+\beta_{1} D M_{i t}+\beta_{2} B C_{i t}+\beta_{3} D M_{i t} \times B C_{i t}+\beta_{4} P V_{i t}+\beta_{5} D M_{i t} \times P V_{i t}+\boldsymbol{\beta} \circ \mathbf{X}_{i t}+\boldsymbol{\beta} \circ \boldsymbol{C}_{\boldsymbol{i}}+\delta_{i t-1}+\mu_{i t}$

where $Y_{i t}$ is the proportion of unlawful measures in country $i$ and year $t, D M_{i t}$ is the average district magnitude, $B C_{i t}$ is the indicator variable for ballot control, and $P V_{i t}$ is the index of the other rules incentivizing the personal vote. $\boldsymbol{\beta} \circ \mathbf{X}_{\boldsymbol{i t}}$ is the Hadamard product of row vectors of betas and control variables (note that GDP per capita is lagged one year), while $\boldsymbol{\beta} \circ \boldsymbol{C}_{\boldsymbol{i}}$ is the Hadamard product of row vectors of betas and country fixed effects that model unobserved unit heterogeneity (Beck and Katz 1995; Wilson and Butler 2007). ${ }^{12}$ The specification includes also a unit-specific first-order autocorrelation coefficient $\delta_{i t-1}$, but we display the results with a common coefficient across countries as well. Our dataset is time-series crosssectional and unbalanced, including fifteen countries in 2000 and twenty-seven in 2012 as 
new member states joined the EU in 2004 and 2007. We employ panel corrected standard errors. The results of these Prais-Winstein models are displayed in Table 1.

\section{TABLE 1 ABOUT HERE}

Models 1 and 2 include only district magnitude in equation (1). They provide evidence in support of the first expectation. Governments of countries where politicians are elected in higher magnitude districts are less likely to adopt unlawful state aid measures. Recall that, on average, eleven every one hundred measures adopted in any given year do not comply with the state aid provisions. A standard deviation increase in District Magnitude, which is approximately equivalent to the difference between the (pre-2005) Italian and Dutch electoral systems, reduces this proportion to ten every one hundred measures. Moving from a singlemember district electoral system to the post-2005 Italian electoral system, which has the highest average district magnitude, halves the proportion for unlawful measures.

Models 3 to 6 include the full specification and Figure 2 displays the marginal effects of District Magnitude on the proportion of unlawful measures in the presence and absence of ballot control (and for different levels of Pool-Vote Rules). Two combinations are excluded because they are logically impossible and, consequently, there are no observations in our dataset. Casting only a single vote for a party in open-list systems would defy the purpose of having a list of candidates to choose from. Hence Pool-Vote Rules never takes the minimum value of zero when there is no ballot control. Equally, casting a single vote for a candidate, without any pooling, is not possible in a closed-list system. Therefore Pool-Vote Rules never takes the maximum value when there is ballot control. 
We do not find evidence that higher district magnitude lowers the proportion of unlawful measures in closed-list systems. If the other rules incentivizing the personal vote take the minimum value (i.e. in case of a single party vote and party-wide pooling), an increase in magnitude has a negative impact which is not however different from zero at the standard level of significance. If these rules take average values, the impact turns positive which is in contradiction with our expectation. On the other hand, an increase in district magnitude unequivocally leads to a higher proportion of unlawful aid in open-list systems. If we set the other rules incentivizing the personal vote at their average values, the proportion of unlawful measures would increase from eleven to at least thirty-two percent with a standard deviation increase in magnitude. If we set these rules at their maximum (e.g. no pooling and multiple or candidate-level voting), the proportion of unlawful measures increases to a considerable sixty-five percent, at least.

Take the Irish single transferable vote system which has candidate-centered features that match somewhat those of single-member-district systems, but where four seats are available on average in any voting district. The resulting tougher competition among copartisans and the stronger incentives to get noticed could explain why the proportion of unlawful measures in Ireland is more than twice as much as it is in Britain or France, exactly as Carey and Shugart (1995) expect.

These results provides strong corroboration in support of (the second part of) our second expectation. If however we focus on the symmetric expectation, the results are less convincing. Recall that this second hypothesis, based on Carey and Shugart (1995), implies that moving from an open-list system to a closed-list system should unequivocally decrease the propensity to adopt unlawful measures, for any value of district magnitude; and that this effect should be stronger when many seats are up for grabs in any given district. We do not 
find support for this symmetric expectation as it is apparent by looking at the positive values of the coefficients of Ballot Control and of the interaction between District Magnitude and Ballot Control in Table 2 (the results hold if we exclude single-member-district systems). This is a further indication that only half of our hypothesis is corroborated. It is worth pointing out nonetheless that the relation between district magnitude and compliance in openlist systems is the opposite to the relation that can be derived from Persson and Tabellini (1999, 2000). Higher magnitude decreases compliance.

We move on now to the third and last expectation which posits a positive interaction between District Magnitude and Pool-Vote Rules. Figure 3 displays the marginal effects of District Magnitude on the proportion of unlawful measures for different levels of Pool-Vote Rules in the absence of ballot control.

\section{FIGURE 3 ABOUT HERE}

A standard deviation increase in District Magnitude raises the proportion of unlawful measures from eleven to thirteen percent if the other rules incentivizing the personal vote are at their minimum values for this subset of observations. Take Slovakia and Latvia, two countries that have recently joined the EU. The proportion of unlawful measures in Slovakia is more than three times as much as in Latvia. Although both electoral systems allow for candidate-level votes, Slovakian politicians compete in a single district to become a member of the 150-seat National Council while Latvian politicians are spread out in five districts to join the 100-seat Saeima. The stronger pressure to establish a personal reputation in Slovakia can explain the greater propensity to infringe the rules.

When Pool-Vote Rules is at their maximum, the proportion of unlawful measures goes from eleven to a considerable sixty five percent, with a standard deviation increase in magnitude. 
On average, the proportion of unlawful measures is tripled. Moreover, an increase in magnitude has a substantially larger effect when Pool-Vote Rules takes the maximum value rather than the mean value. F-tests for the joint significance of the interaction terms reject the null hypothesis that these effects are identical ( $\mathrm{p}$-value $\leq 0.0001$ ). There results therefore strongly corroborate the positive interaction prospected by Carey and Shugart (1995).

Figure 4 displays the same marginal effects of District Magnitude, but in the presence of ballot control. If voters can only choose a party and votes are pooled among all co-partisans (i.e. Pool-Vote Rules takes the minimum value), an increase in magnitude has no effect on compliance. When Pool-Vote Rules is above the minimum, for instance pooling takes place across subsets of co-partisans, such as the regional districts in Spain, or some forms of candidate-level votes are allowed in addition to the party-level vote, a standard deviation increase in magnitude leads to an average increase in the proportion of illegal aid measures from one every ten to one every two measures. Hence an increase in magnitude has a substantially larger effect when Pool-Vote Rules takes the maximum value (for this subset of observations) rather than the minimum value. F-tests for the joint significance of the interaction terms reject the null hypothesis that these effects are identical ( $p$-value $\leq 0.0001$ ). Again, these results corroborate the expected positive interaction between district magnitude and the pool-votes rules. Results hold for the symmetric expectation as well. The marginal effect of Pool-Vote Rules on the propensity to adopt unlawful measures is positive and increasing at increasing values of district magnitude (see Figure A1 in the Appendix).

\section{FIGURE 4 ABOUT HERE}


Lastly, the administrative experience gained over the years in dealing with EU policies facilitates compliance. For instance, the proportion of unlawful measures drops by at least one third in the founding member states compared to the 2004 new entrants. ${ }^{13}$

\section{A closer look at within-country effects of district magnitude}

Electoral rules change slowly over time. Descriptive statistics show that the between-units component of their standard deviation is larger than the within-units component. Therefore our results are driven by differences across countries to a greater extent than by differences within countries. For district magnitude however, within-country variance makes up an appreciable portion of total variance. The average magnitude has changed in twelve states over this time period, in some cases because of redistricting (Denmark, Germany, Ireland and Poland), in others because of peculiarities of the multi-tier system (Austria, Estonia and Hungary), and in yet others because of broader reforms (Belgium, Bulgaria, Greece, Italy and Romania). We complete our empirical investigation paying particular attention to the withincountry effects of district magnitude.

Let $X_{i t}^{d}=X_{i t}-\bar{X}_{\iota}$ be the deviation of variable $X_{i t}$ from the mean $\bar{X}_{l}$ of country $i$ at time $t$. We employ the following specification

$Y_{i t}=\alpha_{0}+\beta_{1} D M_{i t}^{d}+\beta_{2} \overline{D M_{l}}+\beta_{3} B C_{i t}+\beta_{4} P V_{i t}^{d}+\beta_{5} \overline{P V_{l}}+\beta_{6} D M_{i t}^{d} \times B C_{i t}+\beta_{7} \overline{D M_{l}} \times B C_{i t}+\beta_{8} D M_{i t}^{d} \times \overline{P V_{l}}+$ $\beta_{9} \overline{D M_{l}} \times P V_{i t}^{d}+\beta_{10} \overline{D M_{l}} \times \overline{P V_{l}}+\boldsymbol{\beta} \circ \boldsymbol{X}_{i t}^{d}+\boldsymbol{\beta} \circ \overline{\boldsymbol{X}}_{i}+\beta \bar{Y}_{i}+\mu_{i t}$

Each independent and control variable enters the specification as country mean, in order to account for the between-units effects, and as deviation from the country mean in order to account for the within-units effects. The only exception is Ballot Control because it is an indicator variable. The interactions operationalize the hypotheses two and three. ${ }^{14}$ The 
specification includes also the mean proportion $\bar{Y}_{\boldsymbol{i}}$ of unlawful measures in country $i$. The results are displayed in Table 2.

Model 1 provides evidence in support of the first expectation. As the district magnitude increases within countries, governments are less likely to adopt unlawful measures. Moreover, the coefficient of District Magnitude (dev) in Model 1 of Table 2 is close to the respective coefficient in Model 1 of Table 1. Hence, the substantive effect of an increase in magnitude within countries is equivalent to the effect of an increase when within- and between-units components are pooled. In other words, within-units effects carry a greater proportion of explanatory power than between-units effects.

Figure 5 displays the within-country marginal effects of District Magnitude on the proportion of unlawful measures in the presence and absence of ballot control, while Figure 6 displays the same effects for different levels of country-mean Pool-Vote Rules.

\section{FIGURE 5 ABOUT HERE}

\section{FIGURE 6 ABOUT HERE}

An increase in magnitude lowers the proportion of unlawful measures in closed-list systems, but the impact is not sufficiently different from zero at the standard level of significance (see also bottom panels in Figure 6). In open-list systems, higher magnitude leads to a higher proportion of unlawful measures when the other rules incentivizing the personal vote are at their maximum values. This effect can be seen in Figure 5 and in the upper panels of Figure 6 at the right end of the Pool-Vote Rules axis. The proportion of unlawful measures increases from eleven to fifty-six percent with a standard deviation increase in within-country magnitude. The increase in within-country magnitude has a substantially larger effect when Pool-Vote Rules takes the maximum value rather than the minimum value. F-tests for the 
joint significance of the interaction terms reject the null hypothesis that these effects are identical (p-value $\leq 0.000)$.

Within-country effects explain of course a smaller proportion of the variation in our dependent variable, but the results point in the same direction. Consider the Italian electoral reforms in 2005. The switch from a mixed and (mostly) open-list system to a bonus-adjusted closed-list PR system where seats are allocated to parties at the national level is associated with a drop of the proportion of unlawful measures from twelve to five percent per year.

\section{Conclusion}

The recent literature on compliance has begun to shed more light on how electoral incentives shape the propensity of elected leaders to breach international rules. Dai $(2005,2006)$ argues that governments' compliance is primarily responsive to domestic constituencies. Rickard (2010) puts emphasis on the electoral formula and finds that countries with proportional representation are more likely to comply with international agreements.

The present work shows that the electoral formula is not the only institution that matters. Proportional representation does not unequivocally enable international cooperation, but compliance depends on several characteristics of the ballot. Following Persson and Tabellini's $(1999 ; 2000)$ and Carey and Shugart's (1995) expectations, we focus on the interactive effects of district magnitude and ballot structure on the implementation of distributive measures. The combination of these electoral institutions affects the variation in compliance among and within countries.

Employing data on EU state aid control policy, we show that higher district magnitude facilitates compliance. However, higher magnitude may be an obstacle if either party leaders have no control over the ballot rank or other electoral rules strengthen the incentives to cultivate a personal vote. Our findings are robust if we control for regional fiscal autonomy 
(see Table A2), but a future challenge will consist in systematically disentangling the involvement of subnational authorities in granting aid. Furthermore, the results rest on the mutual dependence between the government and the legislature in parliamentary systems, so they may carry over to presidential systems only where presidents heavily depend on legislative cooperation for policy-making.

Nonetheless, this study contributes to two broad research areas. First, it examines in greater depth the determinants of compliance with international obligations. A key issue in the literature is why some countries are more willing to violate international agreements (Simmons 2000; Mansfield et al. 2002; Dai 2006; Rickard 2010). We suggest that electoral institutions may account for the different behaviour of national governments. This is consistent with the argument of Dai (2006) and the work of Rickard (2010) but, unlike previous studies, we illustrate to what extent compliance relies on all the electoral institutions that produce a misalignment between the collective objectives of a government party and the individual objectives of its members. In future research, empirical findings about, for instance, the protectionist tendencies of majoritarian democracies may be similarly qualified. For instance, Rickard (2012b) finds that geographically diffuse sectors obtain more subsidies in party-centred (closed-list) systems than in candidate-centred (open-list) systems. Whether this interaction also leads to less compliance may be worth investigating, but one would have to provide a rationale for governments in closed-list systems to violate the rules.

Second, our findings innovate along several dimensions with regard to the broader literature on EU implementation and compliance, from its ambit (the application of proscriptive provisions) to its causal mechanisms, based on electoral institutions. Some studies have attended to electoral concerns in the attempt to explain outcomes (e.g. Dellmuth and Stoffel 2012; Kaeding 2008; Steunenberg and Rhinard 2010), but none have uncovered the mechanisms we discuss in this work. Whether the results carry over to other EU policies - 
most of which of regulatory nature - is another question and should be object of future research. 


\section{References}

Angelova M., Dannwolf T. and König T. (2012) How Robust Are Compliance Findings? A Research Synthesis. Journal of European Public Policy 19(8): 1269-1291.

Aydin U. (2007) Promoting Industries in the Global Economy: Subsidies in OECD Countries, 1989 to 1995. Journal of European Public Policy 14(1): 115-131.

Aydin U. and Thomas. K. P. (2012) The Challenges and Trajectories of EU Competition Policy in the Twenty-First Century. Journal of European Integration 34(6): 531-547.

Beck N. and Katz J. N. (1995) What to Do (and Not to Do) with Time-Series Cross-Section Data. American Political Science Review 89(3): 634-647.

Benoit K. and Laver M. (2006) Party Policy in Modern Democracies. London: Routledge.

Berglund S., Gange I. and Van Waarden F. (2006) Mass Production of Law. Routinization in the Transposition of European Directives: A Sociological Institutionalist Account. Journal of European Public Policy 13(5): 692-716.

Berry W. D., Golder M. and Milton D. (2012) Improving Tests of Theories Positing Interaction. The Journal of Politics 74(3): 653-671.

Birch S. (2001) Electoral Systems and Party Systems in Europe East and West. Perspectives on European Politics and Society 2(3): 355-377.

Bormann N. and Golder M. (2013) Democratic Electoral Systems around the World, 19462011. Electoral Studies 32(2): 360-369.

Börzel T. A., Hofmann T. and Panke D. (2012) Caving in or Sitting It out? Longitudinal Patterns of Non-Compliance in the European Union. Journal of European Public Policy 19(4): 454-471.

Börzel T. A., Hofmann T., Panke D. and Sprungk C. (2010) Obstinate and Inefficient: Why Member States Do Not Comply With European Law. Comparative Political Studies 43(11): 1363-1390.

Cao X., Prakash A. and Ward M. D. (2007) Protecting Jobs in the Age of Globalization: Examining the Relative Salience of Social Welfare and Industrial Subsidies in OECD Countries. International Studies Quarterly 51(2): 301-327.

Carey J. M. and Hix S. (2013) Consequences of Electoral Rules for Patterns of Redistribution and Regulation. Perspectives on Politics 11(3): 820-824.

Carey J. M. and Shugart M. S. (1995) Incentives to Cultivate a Personal Vote: A Rank Ordering of Electoral Formulas. Electoral Studies 14(4): 417-439.

Chang E. C. C. (2008) Electoral Incentives and Budgetary Spending: Rethinking the Role of Political Institutions. The Journal of Politics 70(4): 1086-1097.

Chang E. C. C. and Golden M. A. (2007) Electoral Systems, District Magnitude and Corruption. British Journal of Political Science 37(1): 115-137.

Chayes A. and Chayes A. H. (1995) The New Sovereignty: Compliance with International Regulatory Agreements. Cambridge: Harvard University Press.

Cini M. and McGowan L. (2008) Competition Policy in the European Union. Basingstoke: Palgrave Macmillan. 
Clark T. S., and Linzer D. A. (2015) Should I Use Fixed or Random Effects? Political Science Research and Methods 3(2): 399-408.

Dai X. (2005) Why Comply? The Domestic Constituency Mechanism. International Organization 59(2): 363-398.

Dai X. (2006) The Conditional Nature of Democratic Compliance. Journal of Conflict Resolution 50(5): 690-713.

Dellmuth L. M. and Stoffel M. F. (2012) Distributive Politics and Intergovernmental Transfers: The Local Allocation of European Union Structural Funds. European Union Politics 13(3): 413-433.

Edwards M. S. and Thames F. C. (2007) District Magnitude, Personal Votes, and Government Expenditures. Electoral Studies 26(2): 338-345.

Falkner G., Hartlapp M. and Treib O. (2007) Worlds of Compliance: Why Leading Approaches to European Union Implementation Are Only 'Sometimes-True Theories.' European Journal of Political Research 46(3): 395-416.

Falkner G., Treib O., Hartlapp M. and Leiber S. (2005) Complying with Europe. New York: Cambridge University Press.

Falkner G., Treib O. and Holzleithner E. (2008) Compliance in the Enlarged European Union: Living Rights Or Dead Letters? Aldershot: Ashgate.

Franchino F. and Mainenti M. (2013) Electoral Institutions and Distributive Policies in Parliamentary Systems: An Application to State Aid Measures in EU Countries. West European Politics 36(3): 498-520.

Franzese R. J. (2002) Macroeconomic Policies in Developed Democracies. Cambridge: Cambridge University Press.

Golden M. A. and Picci L. (2008) Pork-Barrel Politics in Postwar Italy, 1953-94. American Journal of Political Science 52(2): 268-289.

Golder M. (2005) Democratic Electoral Systems around the World, 1946-2000. Electoral Studies 24(1): 103-121.

Hallerberg M. and Marier P. (2004) Executive Authority, the Personal Vote, and Budget Discipline in Latin American and Caribbean Countries. American Journal of Political Science 48(3): 571-587.

Haverland M. and Romeijn M. (2007) Do Member States Make European Policies Work? Analysing the EU Transposition Deficit. Public Administration 85(3): 757-778.

Haverland M., Steunenberg B. and Van Waarden F. (2011) Sectors at Different Speeds: Analysing Transposition Deficits in the European Union. Journal of Common Market Studies 49(2): 265-291.

Hibbs D. A. (1977) Political Parties and Macroeconomic Policy. American Political Science Review 71(4): 1467-1487.

Hille P. and Knill C. (2006) 'It's the Bureaucracy, Stupid' The Implementation of the Acquis Communautaire in EU Candidate Countries, 1999-2003. European Union Politics 7(4): 531-552.

Jensen C. B. (2007) Implementing Europe: A Question of Oversight. European Union Politics 8(4): 451-77. 
Jensen C. B. and Spoon J. (2011) Testing the 'Party Matters' Thesis: Explaining Progress towards Tokyo Protocol Targets. Political Studies 59(1): 99-115.

Johnson J. W. and Wallack J. S. (2007) Electoral Systems and the Personal Vote. http://polisci2.ucsd.edu/jwjohnson/espv.htm.

Kaeding M. (2006) Determinants of Transposition Delay in the European Union. Journal of Public Policy 26(3): 229-253.

(2008) Lost in Translation or Full Steam Ahead: The Transposition of EU Transport Directives across Member States. European Union Politics 9(1): 115-143.

Kassim H. and Lyons B. (2013) The New Political Economy of EU State Aid Policy. Journal of Industry, Competition and Trade 13(1): 1-21.

König T. and Mäder L. (2013) Non-Conformable, Partial and Conformable Transposition: A Competing Risk Analysis of the Transposition Process of Directives in the EU15. European Union Politics 14(1): 46-69.

Laver M. and Hunt W. B. (1992) Policy and Party Competition. London: Routledge.

Lizzeri A. and Persico N. (2001) The Provision of Public Goods under Alternative Electoral Incentives. American Economic Review 91(1): 225-239.

Mansfield E. D., Milner H. V. and Rosendorff P.B. (2002) Why Democracies Cooperate More: Electoral Control and International Trade Agreements. International Organization 56(3): 477-513.

Mastenbroek E. (2005) EU Compliance: Still a 'Black Hole'? Journal of European Public Policy 12(6): 1103-1120.

Mastenbroek E. and Kaeding M. (2006) Europeanization Beyond the Goodness of Fit: Domestic Politics in the Forefront. Comparative European Politics 4(4): 331-354.

Mbaye H. A. D. (2001) Why National States Comply with Supranational Law: Explaining Implementation Infringements in the European Union. European Union Politics 2(3): 259-281.

McGillivray F. (2004) Privileging Industry: The Comparative Politics of Trade and Industrial Policy. Princeton: Princeton University Press.

Milesi-Ferretti G. M., Perotti R. and Rostagno M. (2002) Electoral Systems and Public Spending. Quarterly Journal of Economics 117(2): 609-657.

Nordhaus W. D. (1975) The Political Business Cycle. Review of Economic Studies 42(2): 169-190.

Perkins R. and Neumayer E. (2007) Do Membership Benefits Buy Regulatory Compliance?: An Empirical Analysis of EU Directives 1978-99. European Union Politics 8(2): 180206.

Persson T. and Tabellini G. (1999) The Size and Scope of Government: Comparative Politics with Rational Politicians. European Economic Review 43(4-6): 699-735.

(2000) Political Economics: Explaining Economic Policy. Cambridge: MIT Press.

(2003) The Economic Effects of Constitutions. Cambridge: MIT Press.

(2004) Constitutional Rules and Fiscal Policy Outcomes. American Economic Review 94(1): 25-45. 
Rickard S. J. (2010) Democratic Differences: Electoral Institutions and Compliance with GATT/WTO Agreements. European Journal of International Relations 16(4): 711-729. (2012a) A Non-Tariff Protectionist Bias in Majoritarian Politics: Government Subsidies and Electoral Institutions. International Studies Quarterly 56(4): 777-785.

- (2012b) Electoral Systems, Voters' Interests and Geographic Dispersion. British Journal of Political Science 42(4): 855-877.

Sedelmeier U. (2012) Is Europeanisation through Conditionality Sustainable? Lock-in of Institutional Change after EU Accession. West European Politics 35(1): 20-38.

Shugart M. S., Valdini M. E. and Suominen K. (2005) Looking for Locals: Voter Information Demands and Personal Vote-Earning Attributes of Legislators under Proportional Representation. American Journal of Political Science 49(2): 437-49.

Shugart M. S. (2013) Why Ballot Structure Matters. Perspectives on Politics 11(3): 818-820.

Simmons B. A. (2000) International Law and State Behaviour: Commitment and Compliance in International Monetary Affairs. American Political Science Review 94(4): 819-835.

Steunenberg B. and Rhinard M. (2010) The Transposition of European Law in EU Member States: Between Process and Politics. European Political Science Review 2(3): 495-520.

Sverdrup U. (2008) Implementation. In Graziano P. and Vink M. P. (eds.) Europeanization: New Research Agendas. New York: Palgrave Macmillan, 197-211.

Toshkov D. (2007) Transposition of EU Social Policy in the New Member States. Journal of European Social Policy 17(4): 335-348.

(2008) Embracing European Law Compliance with EU Directives in Central and Eastern Europe. European Union Politics 9(3): 379-402.

Treib O. (2014) Implementing and Complying with EU Governance Outputs. Living Reviews in European Governance 9(1) http://europeangovernance.livingreviews.org/Articles/lreg2014-1.

Versluis E., Van Keulen M. and Stephenson P. (2010) Analyzing the European Union Policy Process. New York: Palgrave Macmillan.

Wallack J. S., Gaviria A., Panizza U. and Stein E. (2003) Particularism around the World. World Bank Economic Review 17(1): 133-143.

Weingast B. R., Shepsle K. A. and Johnsen C. (1981) The Political Economy of Benefits and Costs: A Neoclassical Approach to Distributive Politics. Journal of Political Economy 89(4): 642-664.

Wilson S. E. and Butler D. M. (2007) A Lot More to Do: The Sensitivity of Time-Series Cross-Section Analyses to Simple Alternative Specifications. Political Analysis 15(2): 101-123.

Zahariadis N. (2005) Policy Networks, Elections, and State Subsidies. Review of Policy Research 22(2): 115-131.

(2010) State Aid and Partisan Government in the European Union. Social Science Quarterly 91(2): 436-454. 


\section{Authors:}

Fabio Franchino

Department of Social and Political Sciences, Università degli Studi di Milano

Address: Dipartimento di Scienze Sociali e Politiche, Via Passione 13, 20122 Milano - Italy

E-mail: fabio.franchino@unimi.it

Marco Mainenti

Department of Social and Political Sciences, Università degli Studi di Milano

Address: Dipartimento di Scienze Sociali e Politiche, Via Passione 13, 20122 Milano - Italy

E-mail: marco.mainenti@unimi.it

Funding: the research received no grants from public, commercial or non-profit funding agency. 
Figure 1: Proportion of unlawful state aid measures in EU countries
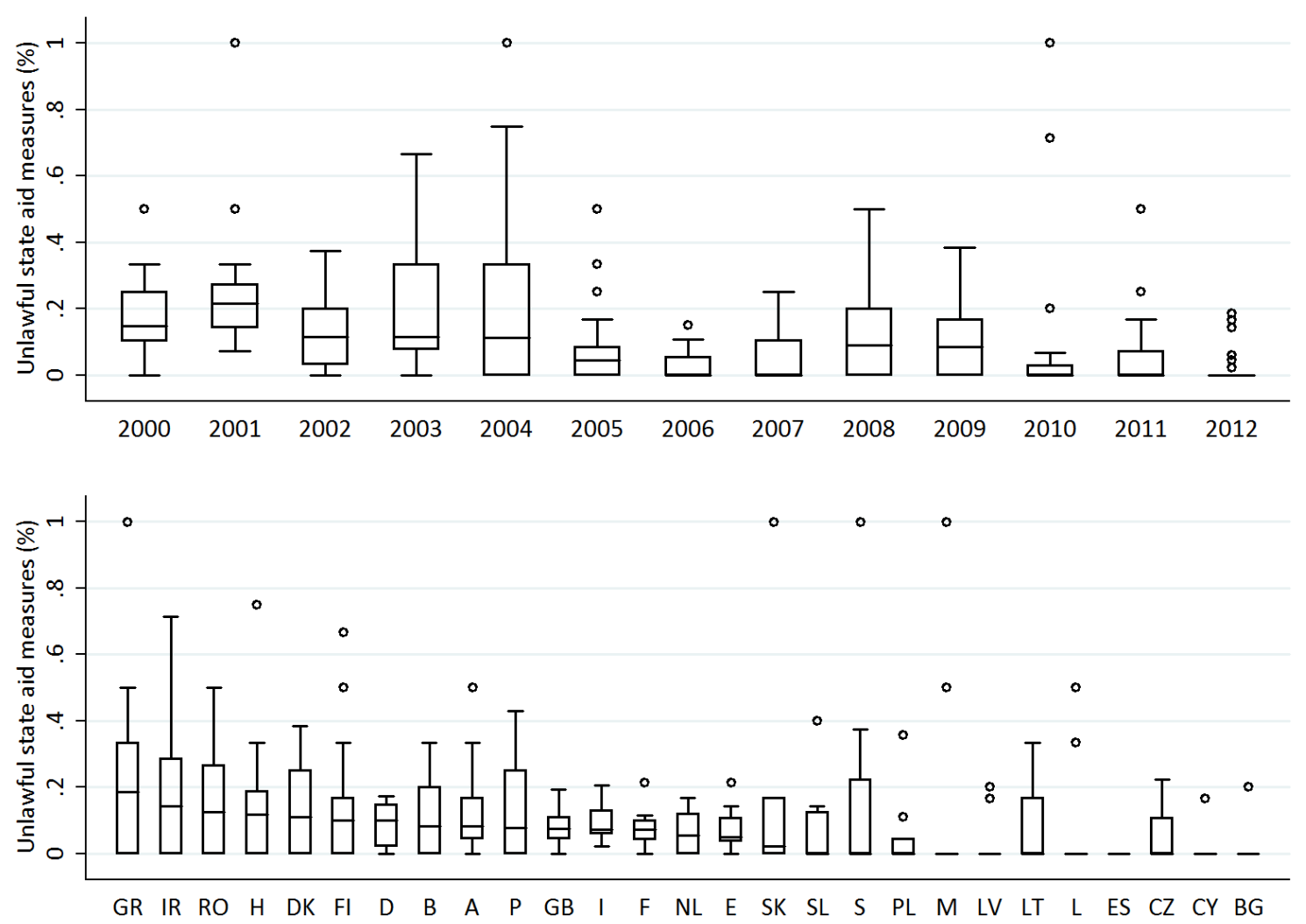

Note: A Austria, B Belgium, BG Bulgaria, CY Cyprus, CZ Czech Republic, D Germany, DK Denmark, E Spain, ES Estonia, F France FI Finland, GB Britain, GR Greece, H Hungary, I Italy, IR Ireland, L Luxembourg, LT Lithuania, LV Latvia, M Malta NL Netherlands, P Portugal, PL Poland, RO Romania, S Sweden, SK Slovakia, SL Slovenia. Source: personal computation of the information available on the official website of the EU Commission; see section on Data and variables. 
Figure 2: Marginal effects of an increase in district magnitude, with and without ballot control


Note: Clockwise from top left panel, models 3 to 6 , Table 1 . The left half of each panel displays the effects in case of no ballot control, the right half in case of ballot control. Pool-Vote Rules cannot take the minimum value of zero in case of no ballot control and the maximum value in case of ballot control. 
Figure 3: Marginal effects of an increase in district magnitude across pool-vote rules
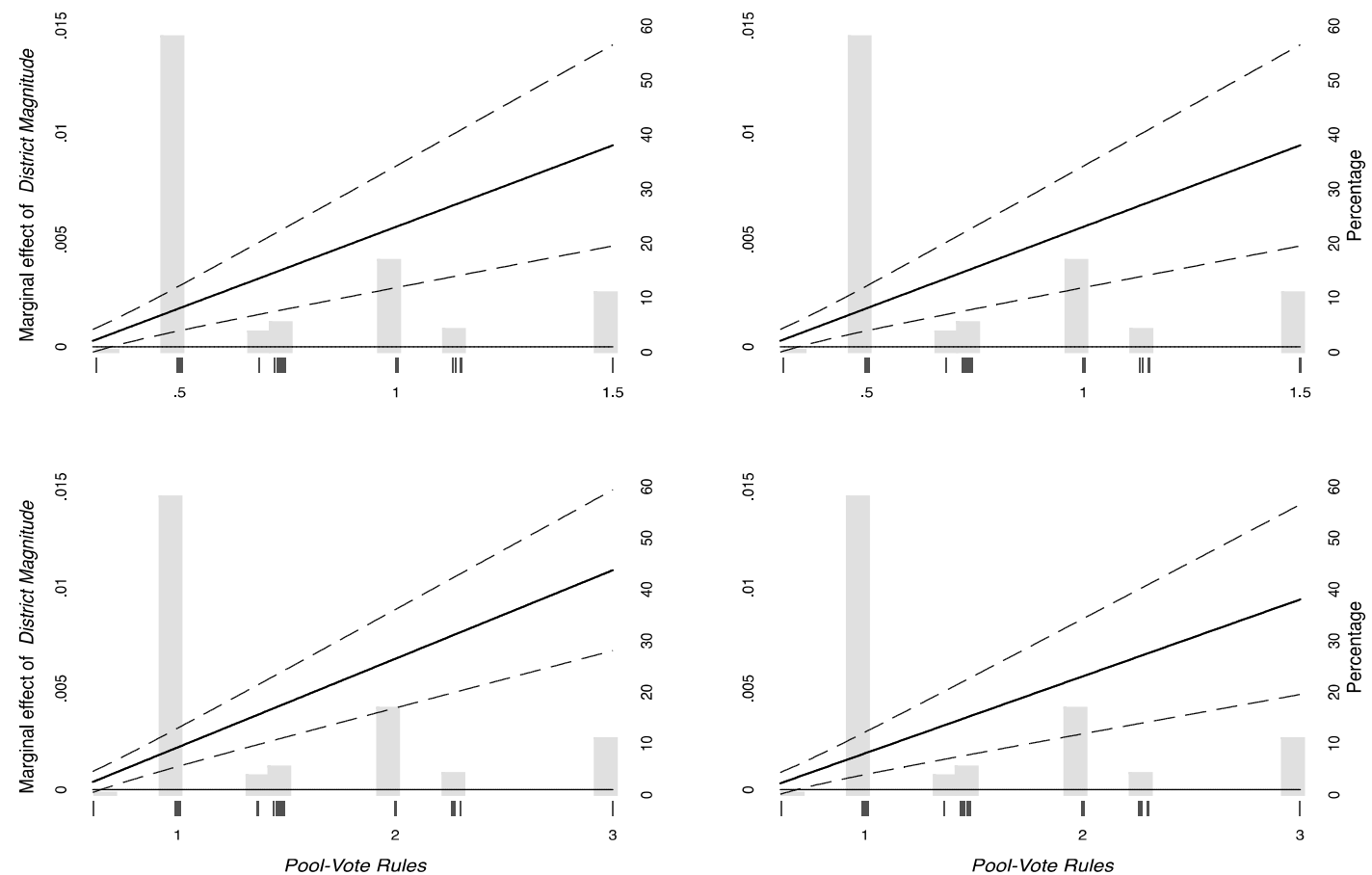

Note: Clockwise from top left panel, models 3 to 6, Table 1. No ballot control. 
Figure 4: Marginal effects of an increase in district magnitude across pool-vote rules in case of ballot control
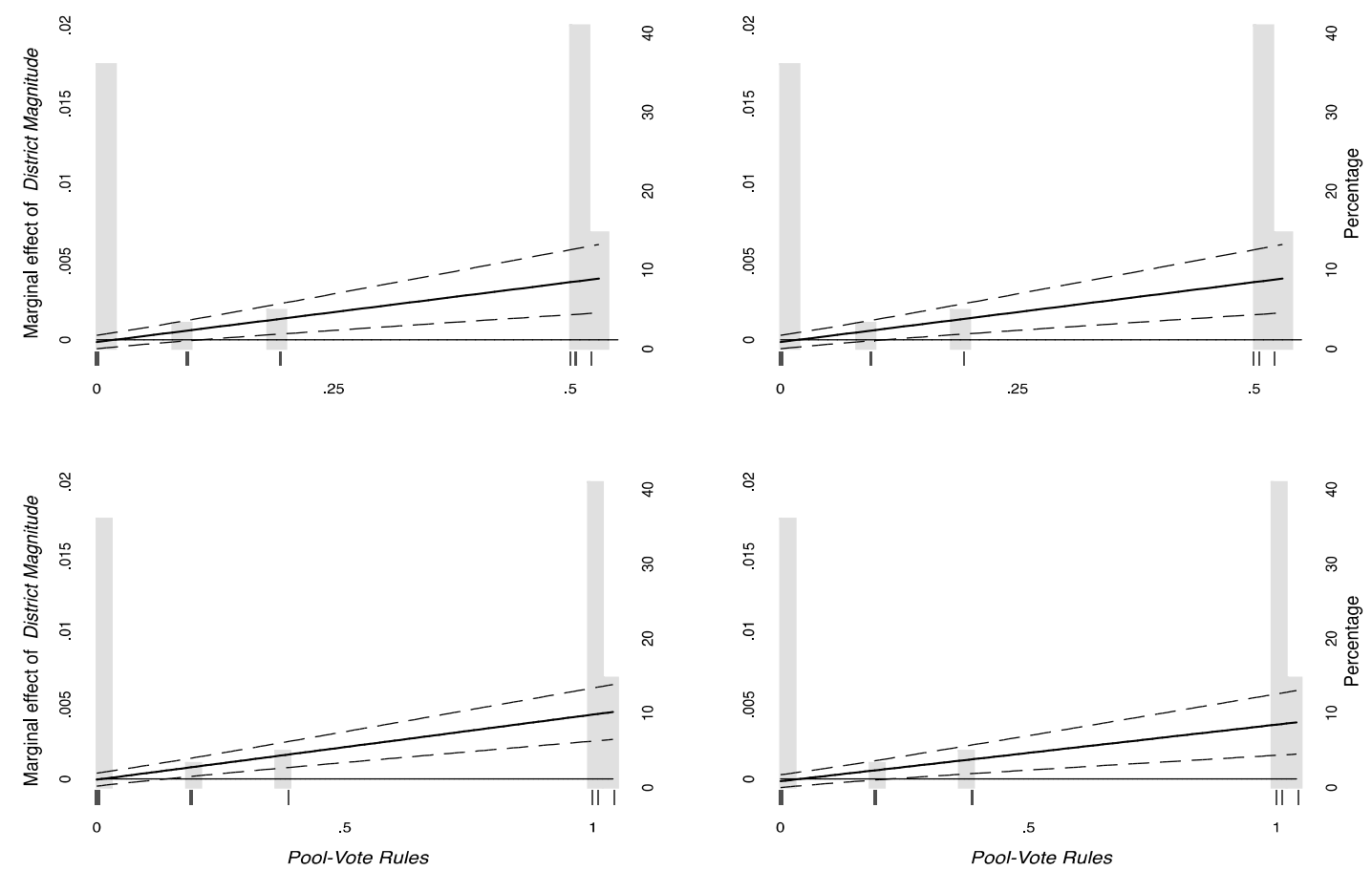

Note: Clockwise from top left panel, models 3 to 6 , Table 1 . 
Figure 5: Marginal effects of a within-country increase in district magnitude, with and without ballot control

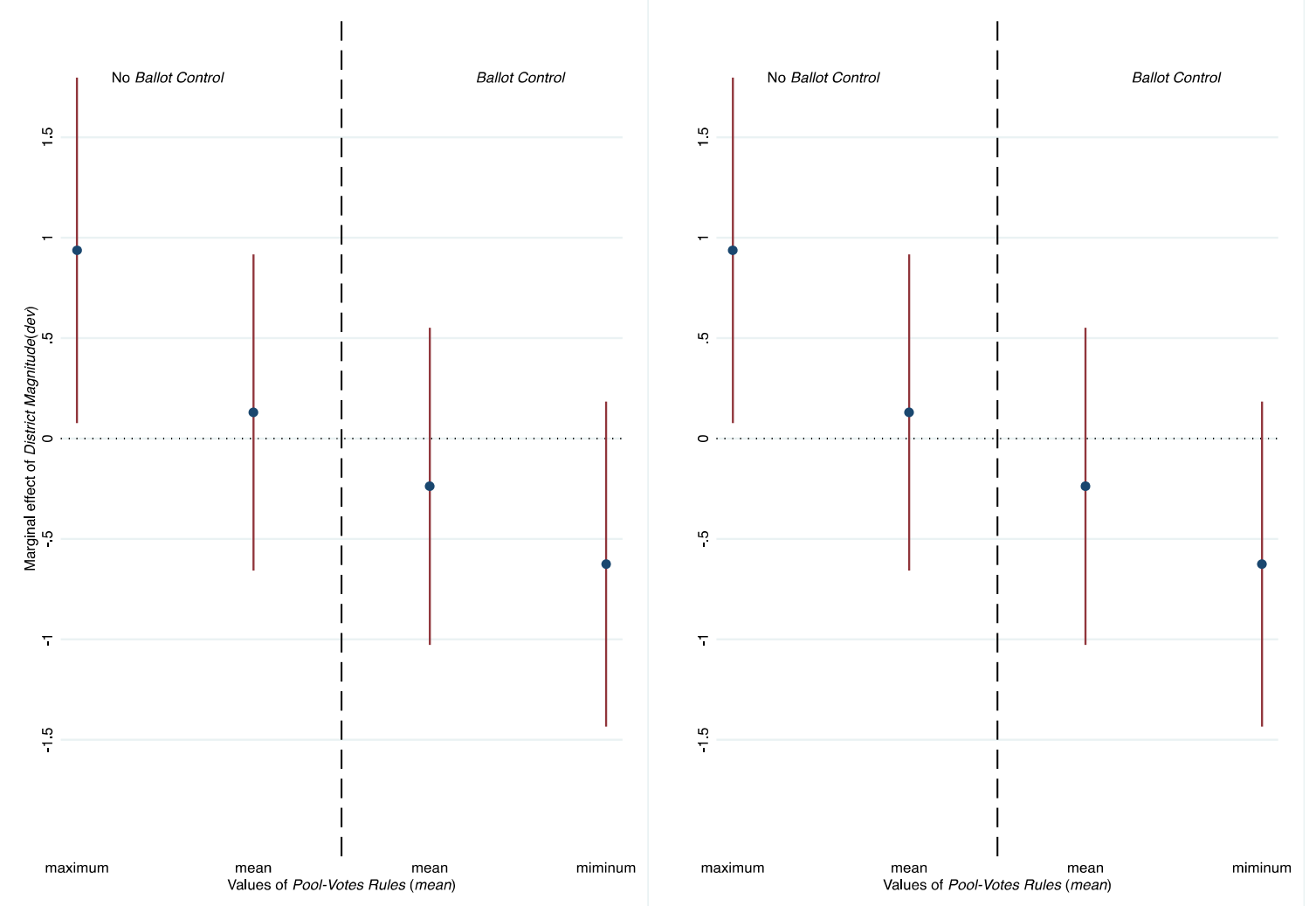

Note: Left panel model 2, right panel model 3, Table 2. The left half of each panel displays the effects in case of no ballot control, the right half in case of ballot control. Pool-Vote Rules (mean) cannot take the minimum value of zero in case of no ballot control and the maximum value in case of ballot control. 
Figure 6: Marginal effects of a within-country increase in district magnitude across pool-vote rules
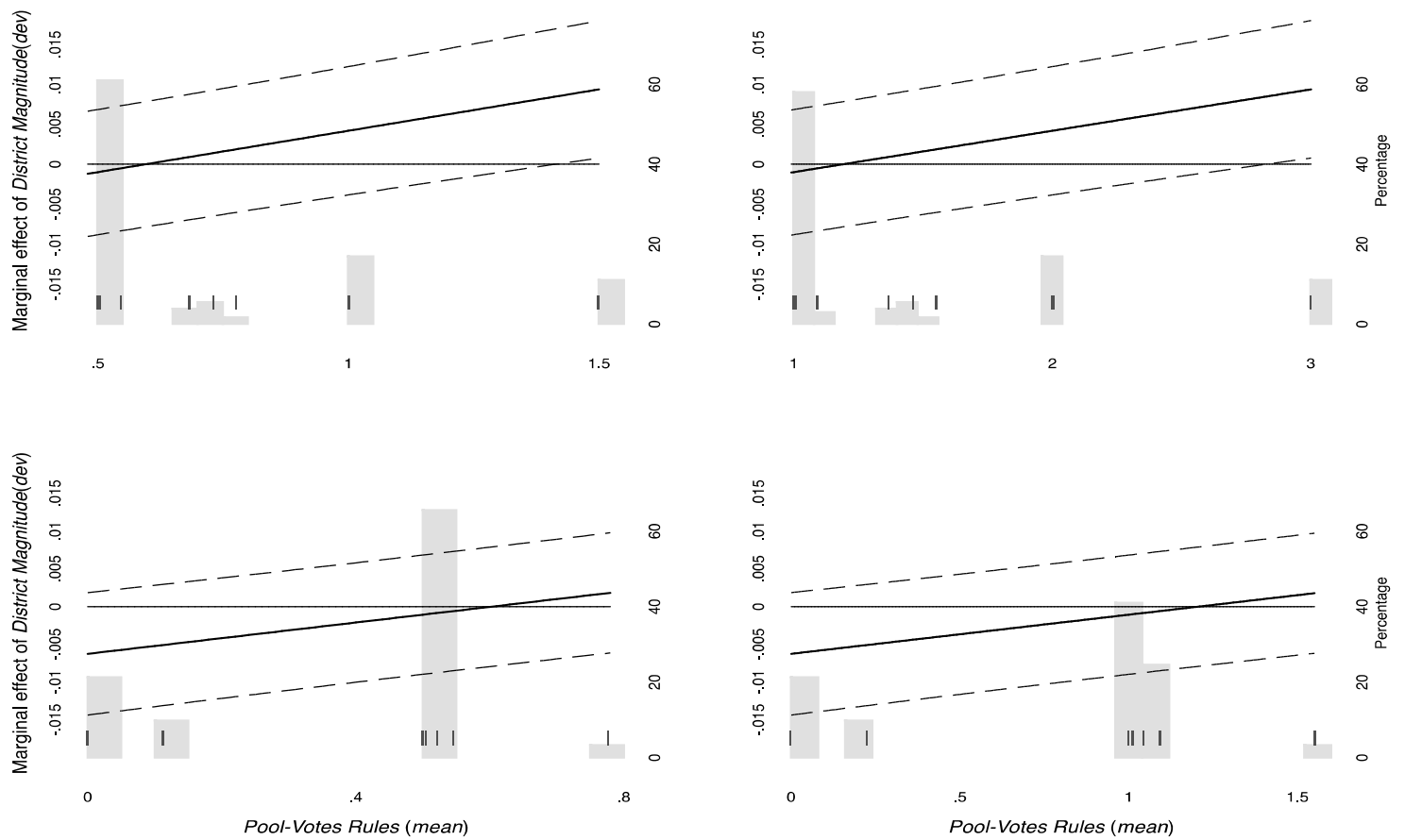

Note: First column model 2, second column model 3, Table 2. Top row without ballot control, bottom row with ballot control. 
Table 1: Electoral institutions and unlawful aid measures, EU countries 2000-2012

(1) (2) (3) $-0.01 * *$
$(0.004)$

$-0.01 * * *$
$(0.003)$

Ballot Control

District Magnitude $\times$ Ballot Control

Poll-Vote Rules

District Magnitude $\times$ Poll-Vote Rules

Election

Government Preference

Years in EU

GDP per capita at $\mathrm{t}-1$

Constant

R-squared

Wald chi2

Rho

AR1 error correction

$\begin{array}{ll}-0.54 & 0.20 \\ (1.860) & (1.719) \\ -0.24 & -0.32 \\ (0.327) & (0.275) \\ -13.34 * * * & -16.23 * * * \\ (3.587) & (4.017) \\ -0.41 & -0.30 \\ (0.774) & (0.730) \\ 62.91 * * & 65.57 * * \\ (28.06) & (26.24) \\ 0.23 & 0.29 \\ 218.0 & 313.2 \\ 0.024 & \end{array}$

\begin{tabular}{llll}
$-0.20 * * *$ & $-0.23 * * *$ & $-0.20 * * *$ & $-0.23 * * *$ \\
$(0.055)$ & $(0.045)$ & $(0.055)$ & $(0.045)$ \\
$10.14 *$ & $9.88^{*}$ & $10.14 *$ & $9.88^{*}$ \\
$(5.389)$ & $(5.089)$ & $(5.389)$ & $(5.089)$ \\
$0.19 * * *$ & $0.26 * * *$ & $0.19 * * *$ & $0.23 * * *$ \\
$(0.058)$ & $(0.048)$ & $(0.058)$ & $(0.048)$ \\
-16.35 & -14.85 & -8.18 & -7.43 \\
$(11.920)$ & $(11.360)$ & $(5.962)$ & $(5.681)$ \\
$0.76 * * *$ & $0.88 * * *$ & $0.38 * * *$ & $0.44 * * *$ \\
$(0.191)$ & $(0.160)$ & $(0.096)$ & $(0.080)$ \\
-0.650 & -0.096 & -0.650 & -0.096 \\
$(1.931)$ & $(1.793)$ & $(1.931)$ & $(1.793)$ \\
-0.280 & -0.347 & -0.280 & -0.347 \\
$(0.343)$ & $(0.296)$ & $(0.343)$ & $(0.296)$ \\
$-13.35 * * *$ & $-17.12 * * *$ & $-13.35 * * *$ & $-17.12 * * *$ \\
$(3.760)$ & $(4.239)$ & $(3.760)$ & $(4.239)$ \\
-0.350 & -0.13 & -0.35 & -0.13 \\
$(0.746)$ & $(0.714)$ & $(0.746)$ & $(0.714)$ \\
$68.14 * *$ & $67.54 * * *$ & $68.14 * *$ & $67.54 * * *$ \\
$(27.61)$ & $(25.86)$ & $(27.61)$ & $(25.86)$ \\
0.25 & 0.32 & 0.25 & 0.32 \\
926.1 & 310.4 & 926.1 & 310.4 \\
-0.015 & & -0.015 & \\
common & unit-specific & $c 09 m 0 n$ & unit-specific \\
\hline
\end{tabular}

(4) (5)

045)

.089)

$23 * * *$

.048)

$5.681)$

$44 * * *$

096

.793)

.347

$7.12 * * *$

.239)

0.13

$54 * * *$

5.86)

common unit-specific common unit-specific parentheses, scaled up by a factor of $100 . * * * p<0.01, * * p<0.05, * p<0.1$. Average of scores of 'pool' and 'vote' in Models 3 and 4 , sum of scores in Models 5 and 6 . 
Table 2: A closer look at within-country effects of district magnitude

\begin{tabular}{|c|c|c|c|}
\hline & (1) & (2) & (3) \\
\hline \multirow[t]{2}{*}{ District Magnitude $(d e v)$} & $-0.00912 * * *$ & -0.617 & -0.617 \\
\hline & $(0.00249)$ & $(0.410)$ & $(0.410)$ \\
\hline \multirow[t]{2}{*}{ District Magnitude (mean) } & $1.90 \mathrm{e}-09 *$ & 0.00879 & 0.00879 \\
\hline & $(1.06 \mathrm{e}-09)$ & $(0.00959)$ & $(0.00959)$ \\
\hline \multirow[t]{2}{*}{ Ballot Control } & & 1.154 & 1.154 \\
\hline & & $(0.867)$ & $(0.867)$ \\
\hline \multirow[t]{2}{*}{ Poll-Vote Rules (dev) } & & -12.94 & -6.469 \\
\hline & & $(11.50)$ & $(5.750)$ \\
\hline \multirow[t]{2}{*}{ Poll-Vote Rules (mean) } & & 0.627 & 0.314 \\
\hline & & $(0.454)$ & $(0.227)$ \\
\hline \multirow[t]{2}{*}{ District Magnitude $(d e v) \times$ Ballot Control } & & -0.00794 & -0.00794 \\
\hline & & $(0.00731)$ & $(0.00731)$ \\
\hline \multirow[t]{2}{*}{ District Magnitude $($ mean $) \times$ Ballot Control } & & -0.00939 & -0.00939 \\
\hline & & $(0.00860)$ & $(0.00860)$ \\
\hline \multirow[t]{2}{*}{ District Magnitude $(d e v) \times$ Poll-Vote Rules $($ mean $)$} & & $1.036 * * *$ & $0.518 * * *$ \\
\hline & & $(0.182)$ & $(0.0908)$ \\
\hline \multirow[t]{2}{*}{ District Magnitude $($ mean $) \times$ Poll-Vote Rules $(\mathrm{dev})$} & & -0.0378 & -0.0189 \\
\hline & & $(0.635)$ & $(0.318)$ \\
\hline \multirow[t]{2}{*}{ District Magnitude $($ mean $) \times$ Poll-Vote Rules $($ mean $)$} & & -0.00470 & -0.00235 \\
\hline & & $(0.0134)$ & $(0.00669)$ \\
\hline \multirow[t]{2}{*}{ Election $(d e v)$} & -0.523 & -0.667 & -0.667 \\
\hline & $(2.195)$ & $(2.239)$ & $(2.239)$ \\
\hline \multirow[t]{2}{*}{ Election (mean) } & $8.36 \mathrm{e}-07$ & -0.393 & -0.393 \\
\hline & $(8.00 \mathrm{e}-07)$ & $(0.855)$ & $(0.855)$ \\
\hline \multirow[t]{2}{*}{ Government Preference (dev) } & -0.241 & -0.336 & -0.336 \\
\hline & $(0.342)$ & $(0.369)$ & $(0.369)$ \\
\hline \multirow[t]{2}{*}{ Government Preference (mean) } & $1.61 \mathrm{e}-08$ & 0.0470 & 0.0470 \\
\hline & $(6.84 \mathrm{e}-08)$ & $(0.0513)$ & $(0.0513)$ \\
\hline \multirow[t]{2}{*}{ Years in EU (dev) } & $-13.18 * * *$ & $-13.38 * * *$ & $-13.38 * * *$ \\
\hline & (3.923) & $(4.248)$ & $(4.248)$ \\
\hline \multirow[t]{2}{*}{ Years in EU (mean) } & $-2.95 e-07$ & -0.165 & -0.165 \\
\hline & $(2.56 \mathrm{e}-07)$ & $(0.141)$ & $(0.141)$ \\
\hline \multirow[t]{2}{*}{ GDP per capita at $\mathrm{t}-1(\mathrm{dev})$} & -0.437 & -0.386 & -0.386 \\
\hline & $(0.301)$ & $(0.309)$ & $(0.309)$ \\
\hline \multirow[t]{2}{*}{ GDP per capita at $\mathrm{t}-1$ (mean) } & $1.01 \mathrm{e}-08$ & 0.00995 & 0.00995 \\
\hline & $(1.58 \mathrm{e}-08)$ & $(0.00931)$ & $(0.00931)$ \\
\hline \multirow[t]{2}{*}{ Unlawful measures (mean) } & $100.0 * * *$ & $102.1 * * *$ & $102.1 * * *$ \\
\hline & $(1.85 \mathrm{e}-06)$ & $(1.980)$ & $(1.980)$ \\
\hline \multirow[t]{2}{*}{ Constant } & $-3.76 e-07$ & -1.232 & -1.232 \\
\hline & $(8.14 \mathrm{e}-07)$ & $(1.278)$ & (1.278) \\
\hline $\mathrm{R}$-squared & 0.235 & 0.248 & 0.248 \\
\hline
\end{tabular}

Notes: $\mathrm{N}=297$, dev deviation from country mean; mean country mean. Coefficient and standard errors, in parentheses, scaled up by a factor of 100 . Errors clustered on country. $* * * p<0.01, * * p<0.05, * p<0.1$. Average of scores of 'pool' and 'vote' in Model 2, sum of scores in Model 3. 
APPENDIX

Table A1: Descriptive Statistics

\begin{tabular}{|c|c|c|c|c|c|}
\hline Variable & Description & Mean & St.Dev. & Min & Max \\
\hline $\begin{array}{l}\text { Unlawful } \\
\text { Measures }\end{array}$ & $\begin{array}{l}\text { Proportion of unlawful aid measures over } \\
\text { total number of aid measures to industry } \\
\text { and services }\end{array}$ & 0.11 & $\begin{array}{l}0.170 \\
0.058^{\mathrm{b}} \\
0.161^{\mathrm{w}}\end{array}$ & 0.00 & 1.00 \\
\hline $\begin{array}{l}\text { District } \\
\text { Magnitude }\end{array}$ & Tier-weighted average district magnitude & 45.97 & $\begin{array}{l}100.333 \\
81.066^{\mathrm{b}} \\
58.801^{\mathrm{w}}\end{array}$ & 1.00 & 617.00 \\
\hline Ballot Control & $\begin{array}{l}1 \text { if a majority of assembly members are } \\
\text { elected under a closed-list electoral } \\
\text { system, } 0 \text { otherwise }\end{array}$ & 0.21 & $\begin{array}{l}0.405 \\
0.394^{\mathrm{b}} \\
0.152^{\mathrm{w}}\end{array}$ & 0.00 & 1.00 \\
\hline Pool-Vote Rules & $\begin{array}{l}\text { Rules incentivizing the personal vote. } \\
\text { Average of scores of 'pool' and 'vote' }\end{array}$ & 0.65 & $\begin{array}{l}0.370 \\
0.340^{\mathrm{b}} \\
0.137^{\mathrm{w}}\end{array}$ & 0.00 & 1.50 \\
\hline & Sum of scores of 'pool' and 'vote' & 1.30 & $\begin{array}{l}0.740 \\
0.681^{\mathrm{b}} \\
0.273^{\mathrm{w}}\end{array}$ & 0.00 & 3.00 \\
\hline Election & $\begin{array}{l}1 \text { in pre-election year, time-weighted } \\
\text { share of } 1 \text { in election year, } 0 \text { otherwise }\end{array}$ & 0.40 & $\begin{array}{l}0.438 \\
0.104^{\mathrm{b}}\end{array}$ & 0.00 & 1.00 \\
\hline $\begin{array}{l}\text { Government } \\
\text { Preference }\end{array}$ & $\begin{array}{l}\text { Portfolio-weighted position of } \\
\text { government parties on taxes-spending } \\
\text { dimension }\end{array}$ & 11.63 & $\begin{array}{l}0.428^{\mathrm{w}} \\
2.698 \\
1.643^{\mathrm{b}} \\
2.209^{\mathrm{w}}\end{array}$ & 5.80 & 17.70 \\
\hline Years in EU & $\begin{array}{l}\text { Log of number of years as EU member } \\
\text { state }\end{array}$ & 2.66 & $\begin{array}{l}1.127 \\
1.093^{\mathrm{b}} \\
0.425^{\mathrm{w}}\end{array}$ & 0.00 & 4.01 \\
\hline GDP per capita & GDP per capita (thousands), at $\mathrm{t}-1$ & 28.43 & $\begin{array}{l}16.807 \\
17.065^{\mathrm{b}} \\
1.999^{\mathrm{w}}\end{array}$ & 4.00 & 87.72 \\
\hline
\end{tabular}

Note: ${ }^{b}$ between-units component of standard deviation, ${ }^{\mathrm{w}}$ within-units component of standard deviation. Source: see section on Data and variables. 
Figure A1: Marginal effects of an increase in pool-vote rules across district magnitude


Note: Single-member electoral district systems excluded. 
${ }^{1}$ We use Treib's review as a benchmark because it is the most recent and comprehensive. The literature is far too vast for a detailed coverage. Moreover, a consensus is emerging on the key determinants of compliance. In another review, Angelova et al. (2012) also identify veto players and goodness of fit as key factors. They refer to 'institutional decision-making' which encompasses the number of veto players and related concepts, such as federalism. For other reviews, see Mastenbroek (2005), Sverdrup (2008) and Versluis et al. (2010).

${ }^{2}$ Lizzeri and Persico (2001), Milesi-Ferretti et al. (2002) and McGillivray (2004) produce models with similar conclusions.

${ }^{3}$ Persson and Tabellini (2003, 169-79, 2004) find more spending on broad (public good-like) entitlement programmes, such as employment insurance, in countries with proportional representation electoral systems but no direct evidence of more distributive spending in countries with majoritarian systems. Milesi-Ferretti et al. (2002), Cao et al. (2007) and Zahariadis (2010) also fail to find direct corroborating evidence. Zahariadis (2005) shows that higher electoral competition leads to more spending on (general and sectoral) aid if there is a trade deficit, and to less spending if trade is balanced. His measure of competition ignores electoral institutions however.

${ }^{4}$ This is not the case for Cyprus, which has a presidential system; but policy-making still needs collaboration between the executive and the legislature. The main results hold if we exclude Cyprus from our analysis.

${ }^{5}$ They also find an effect of district magnitude on corruption in public works contracting in the Italian pre-1994 open-list PR system.

6 'A political decision that concentrates benefits in a specific geographic constituency and finances expenditures through generalised taxation' (Weingast et al. 1981, 644).

7 Managed by the Directorate-General for Competition and available http://ec.europa.eu/competition/elojade/isef/index.cfm?clear=1\&policy_area id=2.

${ }^{8}$ The number of aid measures is the sum total of unlawful and notified measures. The number of notified measures per country and year is available at http://ec.europa.eu/competition/state_aid/statistics/statistics_en.html.

${ }^{9}$ Let $A$ be the size of an assembly and $A=\sum_{i}^{n} S_{i}$, where $S_{i}$ is the number of seats assigned at the electoral tier $i=1 \ldots n$. Let $D_{i}$ be the number of electoral districts in tier $i$. The weighted average district magnitude is $\sum_{i}^{n}\left[\left(S_{i} / D_{i}\right) \times\left(S_{i} / A\right)\right]$. For instance, in the 2003 Estonian elections of the 101-seat Riigikogu, 74 seats were allocated at the 12 lower tier districts and the remaining 27 'compensation mandates' were assigned at the single nation-wide district. The weighted average district magnitude was therefore $[(74 / 12) \times(74 / 101)]+(27 \times 27 / 101)$ $=11.74$. In case of a single electoral tier (i.e. $i=1$ ), $A=S_{i}$ and the formula becomes the standard average district magnitude $A / D_{i}$. The tier at which votes are converted into seats is crucial because this is where candidates concentrate their attention to secure election. For instance, PR seats are allocated on the basis of nation-wide results in Bulgaria, Italy and Germany. In systems where bonus seats are assigned to the largest party (for instance in Greece since 2007), we deduct the number of bonus seats from the number of seats at the lowest tier and from the assembly size. This results in a lower magnitude value, therefore capturing the majoritarian effect of bonus seats. We use data available from Bormann and Golder (2013), Birch (2001), Golder (2005), the election reports of Electoral Studies, and the political data yearbooks of the European Journal of Political Research. In bicameral systems, we use data only from the lower chamber.

${ }^{10} \mathrm{We}$ follow the convention of considering single-member district electoral systems as open-list (Wallack et al. 2003, 137). In these systems, candidate selection is sometimes made through primaries and independent candidates generally face low barrier to enter the electoral competition. Coding these systems as closed-list would overestimate the control that parties have over the ballot, compared to that of voters. 
11 The formula is: (number of completed pre-election months/12) + (number of pre-election days in the incomplete month/total number of days in the incomplete month)/12 (see Franzese 2002, 78). This formula is also used when an explanatory variable changes in a given year. The value in this year is the time-weighted sum of pre-change and post-change values.

12 Hausman tests of fixed- with random-effects models indicate that only the fixed-effects estimator is consistent. Our key independent variables are somewhat sluggish (i.e. between-unit variation is greater than within-unit variation, see Table A1) and we have several units and observations per unit, so a random-effects model does not produce a sufficiently high gain in efficiency to offset the increase in bias (Clark and Linzer 2015).

${ }^{13}$ In Tables A2 to A9, we display several robustness tests. Regional and local authorities may grant state aid, solely or jointly with the central government, or be mere executors of national decisions. The available data provide however limited information about their involvement. Since these authorities may play a greater role if they enjoy more fiscal autonomy, we replicate the analysis in Table A2 by including a measure of regional fiscal autonomy. Table A3 displays negative binomial regressions where the dependent variable is the number of unlawful measures, controlling for the total number of measures. Tables A4 and A5 include respectively public expenditure, as share of GDP, and total aid expenditure to control for different traditions of government intervention in the economy. Table A6 and A7 employ measures of government left-right economic positions and preferences about EU integration derived from Chapel Hill Surveys data. Table A8 includes the full set of additional variables of Tables A2, A4 and A5. Table A9 displays factional logit models. Our findings hold throughout, and the new variables fail to reach the standard level of significance.

${ }^{14}$ Only the interaction between $D M_{i t}^{d}$ and $P V_{i t}^{d}$ is left out because it is not meaningful. 